\title{
Diet of St. Lawrence Estuary Beluga (Delphinapterus leucas) in a changing ecosystem
}

\author{
Véronique Lesage ${ }^{1, *}$, Stéphane Lair ${ }^{2}$, Samuel Turgeon ${ }^{1}$, and Pierre Béland ${ }^{3}$ \\ ${ }^{1}$ Maurice Lamontagne Institute, Fisheries and Oceans Canada, P.O. Box 1000, 850 Route de la Mer, Mont-Joli, Quebec \\ G5H 3 Z4 Canada \\ ${ }^{2}$ Faculté de médecine vétérinaire, Université de Montréal, 3200 Rue Sicotte, St-Hyacinthe, Quebec J2S 2M2 Canada \\ ${ }^{3}$ St. Lawrence National Institute of Ecotoxicology, 6207 Louis-Hébert, Montreal, Quebec H2G 2G6 Canada \\ ${ }^{*}$ Corresponding author: veronique.lesage@dfo-mpo.gc.ca
}

Lesage, V., S. Lair, S. Turgeon, and P. Béland. 2020. Diet of St. Lawrence Estuary Beluga (Delphinapterus leucas) in a changing ecosystem. Canadian Field-Naturalist 134(1): 21-35. https://doi.org/10.22621/cfn.v134i1.2421

\begin{abstract}
Ecosystems and community structure fluctuate over time as a result of natural and anthropogenic factors that may affect prey availability and population dynamics. Most of what we know about St. Lawrence Estuary (SLE) Beluga (Delphinapterus leucas) diet comes from stomach contents collected 80 years ago mainly from a hunting site that Beluga no longer use. How reflective these data are of Beluga diet at other sites and at the current time is unknown. In the context of the recent population decline, general information of prey species alone may help identify useful conservation actions for potentially important prey or habitats. Here, we examined the diet of SLE Beluga using digestive tracts collected from carcasses recovered over the past 30 years, in the context of historical diet data and recent changes in the St. Lawrence ecosystem. We showed they have a varied diet composed of fish and invertebrates generally $<30 \mathrm{~cm}$ in length, and that adult males and females differ in their summer diet in a way that is consistent with the sex segregation observed in this population. Our results also indicate that polychaete worms, squid, and cod are still among the most prevalent prey, and that species such as redfish (Sebastes spp.) might be important prey items. This study shows that Beluga diet has changed since the 1930s, and that prey from digestive tracts identified to species are valuable for making comparisons to the past, and for improving applications of molecular analyses, such as stable isotopes and fatty acids.
\end{abstract}

Key words: Delphinapterus leucas; foraging ecology; diet; Beluga; ecosystem change

\section{Introduction}

Ecosystems and community structure fluctuate over time as a result of a variety of natural and anthropogenic factors. These environmental changes may modify prey availability and affect predator population dynamics. Without contemporary information on diet composition and foraging ecology, predicting a population's response to human stressors and climate variability remains a challenge (Bowen 1997).

A small population of Beluga whale (Delphinapterus leucas) persists in the St. Lawrence Estuary (SLE), Canada (Figure 1), since the last glaciation (Harington 1977). Full protection from hunting since the late 1970s should have allowed this population to grow. Instead, the population has remained stable or may have increased slightly until the early 2000 s but is in a steady decline at a rate of about $1 \%$ per year since then (Mosnier et al. 2015). This led to a change in conservation status from Threatened to Endangered by the Committee on the Status of Endangered
Wildlife in Canada (COSEWIC 2014), and under the Canadian Species at Risk Act (Canada Gazette 2016). Reasons for the lack of recovery and current decline may include contamination, disruption of critical activities by vessel traffic, and reduced access or availability of prey as a result of ecosystem change (DFO 2014). Understanding Beluga diet and foraging ecology may help identify dietary sources of toxic substances, and prey species and habitats most valuable to Beluga recovery.

Most of what we know about SLE Beluga diet comes from stomach contents collected 80 years ago mainly from a hunting site no longer used by SLE Beluga (Vladykov 1946). How reflective these data are of the current Beluga diet and at other sites is uncertain. Since the 1930s, the St. Lawrence marine ecosystem has seen an increase in abundance of potential competitors such as Gray Seal (Halilchoerus grypus) and Harp Seal (Pagophilus groenlandicus; Hammill et al. 2015, 2017), and the collapse of several com- 


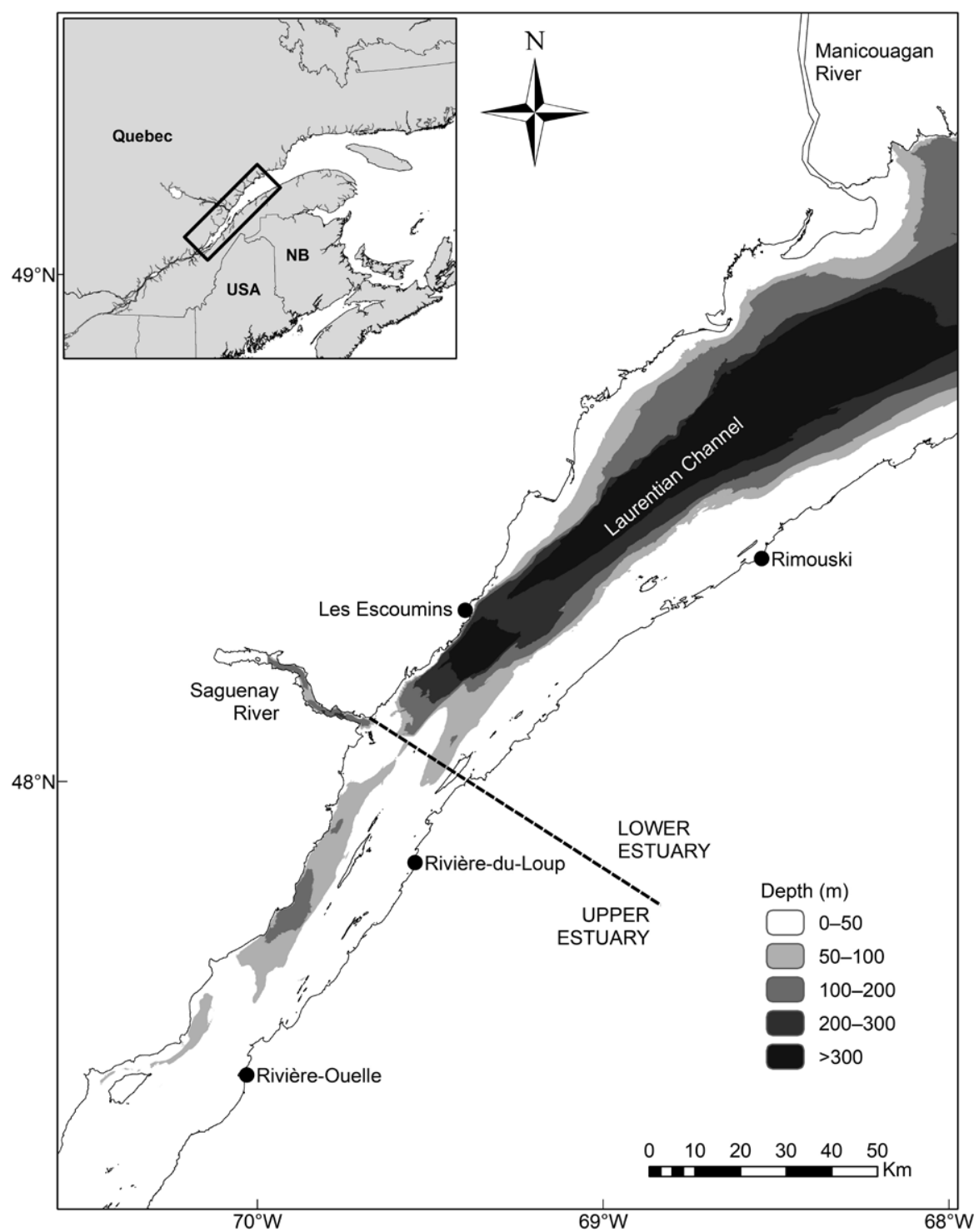

Figure 1. Study area, in the St. Lawrence Estuary, Canada. Upper estuary and lower estuary refer to sectors located west and east of the Saguenay River, respectively. The main hunting site in the Vladykov (1946) study was located on Manicouagan bank, right off Manicouagan River. In our study, Beluga (Delphinapterus leucas) were collected for stomach contents throughout the St. Lawrence Estuary.

mercially exploited demersal fish species, with a concurrent expansion of some crustacean and small pelagic fish stocks (Worm and Myers 2003; Savenkoff et al. 2007). Species such as Northern Shortfin Squid (Illex illecebrosus) and Atlantic (Gadus morhua) or Greenland (Gadus ogac) Cod, which were consumed regularly during the 1930 s, are scarce in recent SLE scientific fisheries, raising questions about their availability to Beluga. American Eels (Anguilla rostrata), which were suspected to be an important source of PCBs and other persistent organic pollutants including Mirex in Beluga, collapsed in the SLE in the 1990s (Hickie et al. 2000; Cairns et al. 2014). Meanwhile, severely depleted fish populations such as redfish (Sebastes spp.) and Striped Bass (Morone saxatilis) are currently rebounding from low levels (COSEWIC 2012; Brassard et al. 2017; DFO 2017; Vanalderweireldt 2019).

Insights into SLE Beluga contemporary diet might be obtained from quantitative dietary mixing mod- 
els that exploit molecular tracers such as stable isotopes or fatty acids (e.g., Iverson et al. 2004; Moore and Semmens 2008; Parnell et al. 2010). However, an important assumption of these models is that all potentially important prey are included in model inputs. Analysis of digestive tracts allows prey to be identified from hard structures such as fish otoliths or bones, cephalopod beaks, and polychaete jaws (Pierce and Boyle 1991). For SLE Beluga, opportunities to sample digestive tracts are limited to animals found dead, the majority of which have empty guts or contain only traces of food as they generally die after a period of anorexia (Lair et al. 2016). While these samples are unsuitable for quantitative diet assessment, they are valuable for identifying current prey species for comparison to the past and for other diet analyses. In the context of the recent population decline, identifying prey species may guide conservation actions important for SLE Beluga. Here, we examine the contemporary diet of SLE Beluga using digestive tracts collected from carcasses recovered over the past 30 years, in the context of historical diet data and recent changes in trophic structure of the St. Lawrence ecosystem.

\section{Methods}

Starting in 2007, digestive tracts were collected from well-preserved or moderately decomposed (freshness codes $\leq 3$; Geracy and Lounsbury 1993) Beluga reported dead in the SLE and examined systematically for prey remains using standard protocols (Hammill et al. 2005). Sex and age were available for each individual; only individuals one year or older (i.e., likely to have ingested solid food; Brodie 1971; Matthews and Ferguson 2015) were included in the analysis. Age was determined from tooth dentinal layers, using a longitudinal midline section or half tooth, and highresolution (4800 dpi optical resolution, 24-bit colour) digital imagery (Epson scanner Perfection V500 photo, Epson Canada Limited, Markham, Ontario, Canada) to allow for magnification, light, and contrast adjustments. One growth layer group (GLG) was assumed to be deposited each year (Stewart et al. 2006; Hohn et al. 2016; Waugh et al. 2018).

Digestive tracts were first examined for potential lesions. They were then extracted and frozen at $-20^{\circ} \mathrm{C}$ until shipping and analysis for contents. They were confined to clean trays during the exam to avoid content loss. However, volume and mass of prey remains are likely to be imprecise due to digestion and are not reported here. Stomach and intestinal contents were examined separately but are presented in combination for this study. Each of the four stomach compartments were rinsed three times to ensure full recovery of contents. Stomach contents were then sorted using a fine mesh sieve $(125 \mu \mathrm{m})$. Prey remains were identified to the lowest taxon possible using hard parts (i.e., otoliths and bones for fish, and beaks for cephalopods; Clarke 1986; Murie and Lavigne 1986).

Otoliths were assigned to one of three classes depending on degradation state. Class 1 included well preserved otoliths, Class 2 those eroded along margins but with few degradation marks, and Class 3 otoliths with erosion on both dorsal and ventral margins and internal and external areas. Prey size was estimated using otolith length/fish length relationships developed from samples collected during research cruises from Fisheries and Oceans Canada or using values from the literature (Bowen and Harrison 1996; Proust 1996; Hammill et al. 2007). A random subsample of 30 otoliths per species was measured when a large number of otoliths was present in a sample. Few Class 1 and 2 otoliths were obtained from the decaying Beluga carcasses; Class 3 otolith were also measured and reported separately to provide fish length minima. Given the small number of digestive tracts with some content (see Results), no attempt was made to quantify diet composition in terms of energy or mass contributions. Prey items were analyzed for frequency of occurrence only (Bowen and Harrison 1996). Empty stomachs were excluded from calculations.

\section{Results}

Between 2007 and 2019, 79 Beluga were examined systematically for prey remains. An additional 10 Beluga with prey remains sampled in the late 1980s ( $n$ $=2)$, mid-1990s $(n=2)$, and early 2000s $(n=6)$ were also included in this study. The sample $(n=89)$ was skewed toward females (61 females versus 28 males), mature individuals ( $87 \%$ were eight years or older), and ice-free months (only four carcasses collected during winter, i.e., December through March). Fiftyseven percent $(45 / 79)$ of the systematically examined digestive tracts (i.e., 2007 onward) contained identifiable prey remains, with $13 \%(10 / 79)$ of the tracts having food in more than trace amounts, i.e., more than 15 otoliths or invertebrate parts.

Twenty-eight taxa, 18 fish and 10 invertebrate species, were represented in digestive tracts (Table 1; detailed diet data in Table S1). On average, 2.4 (SD = 2.2) prey species were detected per Beluga, although 11 different species were detected in one Beluga (nine fish, two invertebrates). Our limited data on fullness indices show no evidence for a fast and feast pattern over seasons in this population (Figure 2). Prey diversity in digestive tracts that contained food in amounts greater than trace, varied among months, but without following a clear seasonal pattern (Table 2). Both invertebrate and fish prey were detected in 
TABLE 1. Species frequency of occurrence (\% of digestive tracts with prey remains) in the diet of Beluga (Delphinapterus leucas) hunted mainly at the Banc de Manicouagan in 1938-1939 (Vladykov 1946: 60), or collected in various regions of the St. Lawrence Estuary via Beluga carcass recovery between 1989 and 2019 (our study).

\begin{tabular}{|c|c|c|c|c|}
\hline \multirow{2}{*}{ Taxon } & \multicolumn{2}{|c|}{ Vladykov 1938-1939 } & \multicolumn{2}{|c|}{ Our study 1989-2019 } \\
\hline & $n$ & $\%(n=107)$ & $n$ & $\%(n=59)$ \\
\hline FISHES & 107 & & 36 & \\
\hline \multicolumn{5}{|l|}{ Ammodytidae } \\
\hline Sand lance (Ammodytes sp.) & 58 & 54 & 4 & 7 \\
\hline \multicolumn{5}{|l|}{ Clupeidae } \\
\hline Atlantic Herring (Clupea harengus) & 2 & 2 & 2 & 3 \\
\hline \multicolumn{5}{|l|}{ Osmeridae } \\
\hline Capelin (Mallotus villosus) & 54 & 51 & 7 & 12 \\
\hline Rainbow Smelt (Osmerus mordax) & 1 & 1 & 4 & 7 \\
\hline \multicolumn{5}{|l|}{ Scombridae } \\
\hline Atlantic Mackerel (Scomber scombrus) & - & & 1 & 2 \\
\hline \multicolumn{5}{|l|}{ Gadidae } \\
\hline Atlantic Cod/Greenland Cod (Gadus morhua/Gadus ogac) & 45 & 42 & 10 & 17 \\
\hline Atlantic Cod (Gadus morhua) & - & & 3 & 5 \\
\hline Atlantic Tomcod (Microgadus tomcod) & 18 & 17 & 1 & 2 \\
\hline Haddock (Melanogrammus aeglefinus) & 2 & 2 & - & \\
\hline White Hake (Urophycis tenuis) & - & & 5 & 8 \\
\hline Silver Hake (Merluccius bilinearis) & - & & 1 & 2 \\
\hline Red Hake (Urophycis chuss) & 1 & 1 & - & \\
\hline Fourbeard Rockling (Enchelyopus cimbrius) & - & & 3 & 5 \\
\hline Ocean Pout (Zoarces americanus)/Lycodes sp. & 2 & 2 & 2 & 3 \\
\hline Gadidae (unspecified) & - & & 5 & 8 \\
\hline \multicolumn{5}{|l|}{ Macrouridae } \\
\hline Marlin-spike (Nezumia bairdii) & - & & 2 & 3 \\
\hline \multicolumn{5}{|l|}{ Scorpaenidae } \\
\hline Redfish (Sebastes sp.) & - & & 9 & 15 \\
\hline \multicolumn{5}{|l|}{ Cyclopteridae } \\
\hline Snailfish (Liparis sp.)* & 4 & 4 & 1 & 2 \\
\hline Lumpfish (Cyclopterus lumpus) & 1 & 1 & 1 & 2 \\
\hline \multicolumn{5}{|l|}{ Cottidae } \\
\hline Sculpins (Myoxocephalus sp.) & 35 & 33 & 1 & 2 \\
\hline Daubed Shanny (Leptoclinus maculatus) & - & & 1 & 2 \\
\hline Cottidae (unspecified) & - & & 3 & 5 \\
\hline \multicolumn{5}{|l|}{ Anguillidae } \\
\hline American Eel (Anguilla rostrata) ${ }^{\dagger}$ & - & & 1 & 2 \\
\hline \multicolumn{5}{|l|}{ Pleuronectidae } \\
\hline Witch Flounder (Glyptocephalus cynoglossus) & 1 & 1 & - & \\
\hline Winter Flounder (Pseudopleuronectes americanus) & 9 & 9 & 1 & 2 \\
\hline Smooth Flounder (Pleuronectes putnami) & 5 & 5 & 1 & 2 \\
\hline \multicolumn{5}{|l|}{ Rajidae } \\
\hline $\begin{array}{l}\text { Smooth and Thorny Skate (Malacoraja senta, Amblyraja radiata, } \\
\text { and skate sp.) }\end{array}$ & 6 & 6 & - & \\
\hline \multicolumn{5}{|l|}{ Petromyzontidae } \\
\hline Sea Lamprey (Petromyzon marinus) & 2 & 2 & - & \\
\hline \multicolumn{5}{|l|}{ Acipenseridae } \\
\hline Atlantic Sturgeon (Acipenser oxyrinchus) & 3 & 3 & - & \\
\hline
\end{tabular}


TABLE 1. Continued.

\begin{tabular}{|c|c|c|c|c|}
\hline \multirow{2}{*}{ Taxon } & \multicolumn{2}{|c|}{ Vladykov 1938-1939 } & \multicolumn{2}{|c|}{ Our study $1989-2019$} \\
\hline & $n$ & $\%(n=107)$ & $n$ & $\%(n=59)$ \\
\hline \multicolumn{5}{|l|}{ Salmonidae } \\
\hline Atlantic Salmon (Salmo salar) & 1 & 1 & - & \\
\hline INVERTEBRATES & 91 & & 28 & \\
\hline \multicolumn{5}{|l|}{ Polychaeta } \\
\hline polychaete worm (Nereis virens) & 64 & 60 & 23 & 39 \\
\hline Cistenides gouldii & 22 & 21 & - & \\
\hline \multicolumn{5}{|l|}{ Crustacea } \\
\hline Decapod shrimp & 69 & 65 & 9 & 15 \\
\hline Amphipod gammarid & 37 & 35 & 1 & 2 \\
\hline Other & 4 & 4 & - & \\
\hline \multicolumn{5}{|l|}{ Mollusca } \\
\hline $\begin{array}{l}\text { Gastropods Waved Whelk (Buccinum undatum) and periwinkle } \\
\text { (Littorina sp.) }\end{array}$ & 19 & 18 & 4 & 7 \\
\hline Bivalvia lamellibranch (Cyrtodaria/Mesodesma) & 37 & 35 & 1 & 2 \\
\hline Cephalopod Northern Shortfin Squid (Illex illecebrosus) & 35 & 33 & 5 & 8 \\
\hline Cephalopod Northern Atlantic Octopus (Bathypolypus bairdii) ${ }^{*}$ & 21 & 20 & 3 & 5 \\
\hline Cephalopod (unspecified) & - & & 2 & 3 \\
\hline Other & 68 & 64 & - & \\
\hline
\end{tabular}

*Named Neoliparis atlanticus in Vladykov (1946).

$\dagger$ Most likely identification from eroded otolith.

${ }^{\star}$ Bathypolypus obesus in Vladykov (1946).

digestive tracts (Table 1). Fish with the highest occurrences were demersal species, i.e., cod (either or both G. morhua and G. ogac), redfish (Sebastes sp.) and hake (White [Urophycis tenuis] and Silver [Merluccius bilinearis] Hake), with occurrences varying from 10 to $22 \%$. Small pelagic or bottom-dwelling species such as Capelin (Mallotus villosus), sand lance (Ammodytes sp.), and Rainbow Smelt (Osmerus mordax) were present in 12,7 , and $7 \%$ of the tracts, respectively. Among invertebrates, polychaete worms were the most common prey with a $39 \%$ occurrence, followed by decapod shrimp (15\%) and Northern Shortfin Squid (8\%).

There was no clear seasonal trend in different prey occurrences in SLE Beluga in general or by sex (not shown). However, some patterns emerged when examining prey assemblages in individual Beluga per sector/month. Except for one adult male sampled at Rivière-Ouelle (upper estuary) in early May, which contained 1933 Capelin otoliths, all other Beluga sampled in the upper estuary between June and September $(n=8)$ were adult females. The females fed on small pelagic or bottom-dwelling fish such as Capelin, sand lance, Atlantic Herring (Clupea harengus) or Rainbow Smelt, on Northern Shortfin Squid and polychaete worms, and on prey not reported elsewhere in the SLE, which included Atlantic Tomcod (Microgadus tomcod), Smooth Flounder (Pleuronectes putnami), and Winter Flounder (Pseudopleuronectes americanus). Although some Beluga found dead in the lower estuary might have drifted there from the upper estuary, lower estuary Beluga differed from upper estuary Beluga by including both females and males that contained multiple demersal fish species, including cod (Atlantic or Greenland Cod), redfish, and White and Silver Hake. Note that while Atlantic Cod were specifically identified among prey remains in three samples, cod otoliths in seven other samples were too eroded to be identified to species as Atlantic or Greenland Cod.

Polychaete worms, Capelin, hakes, and cephalopods (Northern Shortfin Squid or Northern Atlantic Octopus [Bathypolypus bairdii]) followed no clear gender-based, seasonal, or spatial trends in our sample. However, some species showed a seasonal pattern in Beluga digestive tracts: American Eels were detected only in October (one Beluga); sand lance and Atlantic Herring only in April or September samples; and Rainbow Smelt only in April, and then from late August through October (Figure 3). Demersal fish species from the families Zoarcidae, Macrouridae, Liparidae, Cyplopteridae, and Cottidae, were found in trace amounts in samples, and only outside of summer months, i.e., in April, May, and from September 


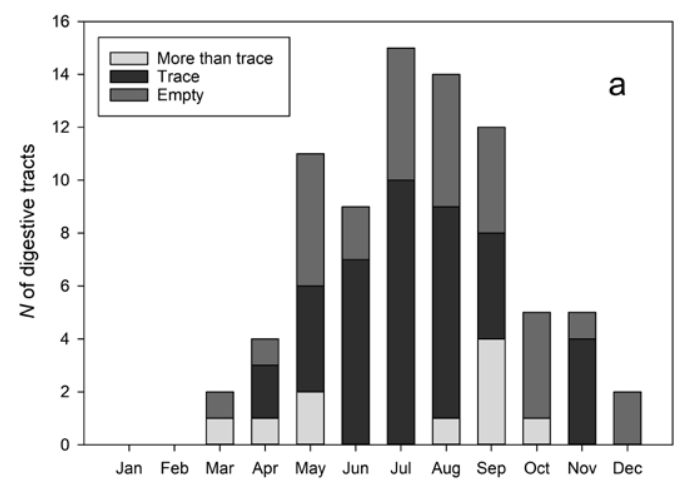

Month

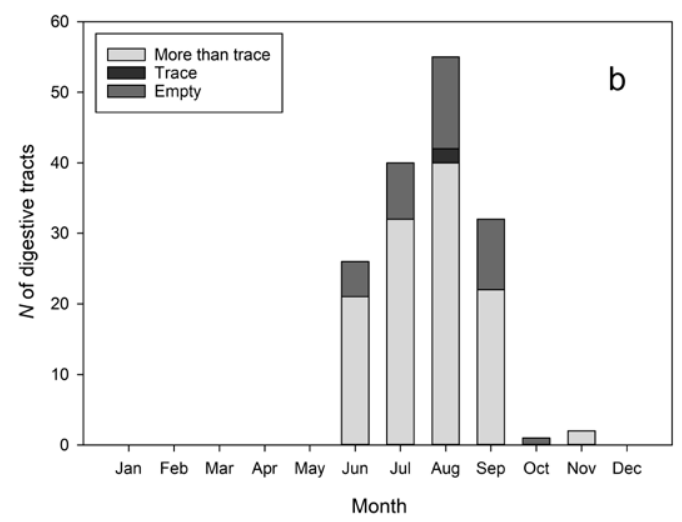

Figure 2. Seasonal distribution of Beluga (Delphinapterus leucas) digestive tract sampling in a. our study (2007 and onward) and b. that of Vladykov (1946), and relative index of contents volume. A 'Trace' content had fewer than 15 otoliths or invertebrate identifiable parts.

through November. Males consumed redfish in all sampled seasons, while females only in April, or September and October (Figure 4).

The estimated overall mean length of prey found in SLE Beluga digestive tracts using unworn or moderately worn otoliths was $19.8 \mathrm{~cm}(\mathrm{SE}=1.2 \mathrm{~cm}, n$ $=97$, range $5.9-54.8 \mathrm{~cm}$ ), and when including worn otoliths was $20.3 \mathrm{~cm}(\mathrm{SE}=0.4 \mathrm{~cm}, n=533$, range $4.6-54.8 \mathrm{~cm}$ ). This mean value changed little (by 0.4 $0.5 \mathrm{~cm}$ ) depending on whether cod otoliths were assumed to be Atlantic or Greenland Cod. The smallest fish consumed were Capelin with a mean length of $11.4 \mathrm{~cm}(\mathrm{SE}=0.15 \mathrm{~cm} ; n=49)$, while the largest were White Hake with a mean length of $45.9 \mathrm{~cm}(\mathrm{SE}=2.97$ $\mathrm{cm} ; n=4)$. With the exception of Atlantic/Greenland Cod and hake, most Beluga preys were on average 30 $\mathrm{cm}$ or less in length (Table 3, Figure 5).

\section{Discussion}

A variety of physiological and ecological factors can influence prey selection, energy intake, and
TABLE 2. Monthly diet diversity expressed as the mean number of taxa detected in digestive tracts containing prey remains in more than trace amounts ( $\geq 15$ hard parts) for St. Lawrence Estuary Beluga (Delphinapterus leucas) hunted at three different sites in the late 1930s (Vladykov 1946; see Figure 1), or found dead between 1983 and 2019 (our study). Sample size is indicated in parentheses.

\begin{tabular}{lcccc}
\hline \hline Month & $\begin{array}{c}\text { Our } \\
\text { study } \\
(n=16)\end{array}$ & $\begin{array}{c}\text { Manicou- } \\
\text { agan } \\
(n=89)\end{array}$ & $\begin{array}{c}\text { Lescoumins } \\
(n=16)\end{array}$ & $\begin{array}{c}\text { Rivière- } \\
\text { Ouelle } \\
(n=2)\end{array}$ \\
\hline Jan & - & - & - & - \\
Feb & - & - & - & - \\
Mar & $2(1)$ & - & - & - \\
Apr & $6(1)$ & - & - & - \\
May & $2(3)$ & - & - & - \\
June & - & $2.8(13)$ & $6.3(7)$ & - \\
July & $5(1)$ & $3.9(24)$ & $6(8)$ & - \\
Aug & $3.5(2)$ & $7.3(31)$ & $7(1)$ & - \\
Sep & $5.8(5)$ & $5.2(21)$ & - & - \\
Oct & $7(2)$ & - & - & - \\
Nov & $4(1)$ & - & - & $5(2)$ \\
Dec & - & - & - & - \\
\hline \hline
\end{tabular}

feeding strategies of marine predators like Beluga (Stephens and Krebs 1986). These include prey availability and energy content, the predator's energy requirements, behavioural and physiological constraints such as those that body size or the presence of a dependant calf impose on prey type and size, and on dive duration and depth (Salton et al. 2019). Seasonal and spatial patterns that are observed in diet composition among populations or among individuals of different reproductive, age, or sex classes likely reflect some of these constraints.

The Estuary and Gulf of St. Lawrence like other ecosystems worldwide have undergone profound ecosystemic changes as a result of overfishing and ocean warming (Worm and Myers 2003; Stenseth et al. 2004). An analysis incorporating 94 physical and biological variables over a 40 -year period for the Gulf of St. Lawrence underscored the massive drop in demersal fish biomass in the early 1990s, the increase in atmospheric and water temperatures, and decrease in sea ice extent and thickness since 2000, with extremes recorded since 2010 (Plourde et al. 2014). While we know little about prey abundance in the 1930s, environmental changes since the 1990s likely affected Beluga prey availability in recent times. The abundance of potential competitors to SLE Beluga also changed since the 1930s. They include Harp Seals, Grey Seals, juvenile Harbour Seals (Phoca vitulina), and female Hooded Seals (Cystophora cristata), 

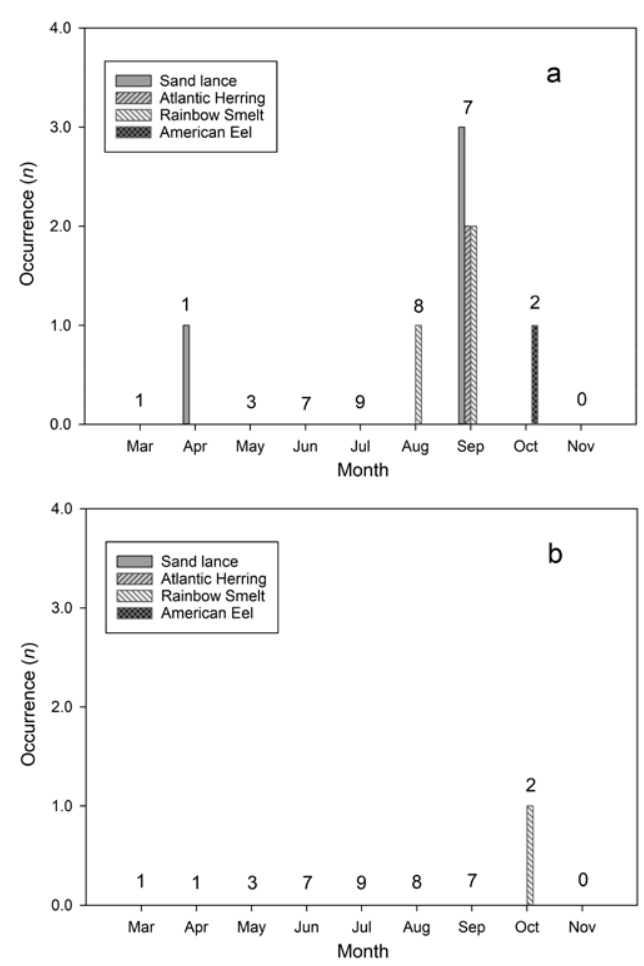

Figure 3. Seasonal occurrence of Sand lance (Ammodytes sp.), Atlantic Herring (Clupea harengus), Rainbow Smelt (Osmerus mordax), and American Eel (Anguilla rostrata) in digestive tracts of a. female and b. male St. Lawrence Estuary Beluga (Delphinapterus leucas) collected between 1988 and 2019. Numbers of tracts with at least trace amounts of food are indicated above each set of bars.

which occupy trophic positions similar to adult female and male Beluga (Lesage et al. 2001). Baleen whales occupy lower trophic positions but share prey items with Beluga (Gavrilchuk et al. 2014). Several of these populations are increasing in size (Stevick et al. 2003; Hammill and Stenson 2006; Hammill et al. 2010, 2015, 2017), but competition extent has not been documented.

Similarities but also differences were observed when comparing present and past diet of SLE Beluga. Sand lance and Capelin were prey with the highest occurrences in SLE Beluga stomachs in the 1930s (Vladykov 1946), while large demersal fish such as cod, hake, and redfish were the most frequent fish prey in our study. Redfish, American Eel, and two species of hake were present in Beluga contemporary diet but were undetected in Vladykov's study. The reverse was noted for Atlantic Salmon (Salmo salar), Atlantic Sturgeon (Acipenser oxyrinchus), Sea Lamprey (Petromyzon marinus), Haddock (Melanogrammus aeglefinus), and skates. Polychaete worms and cephalopods
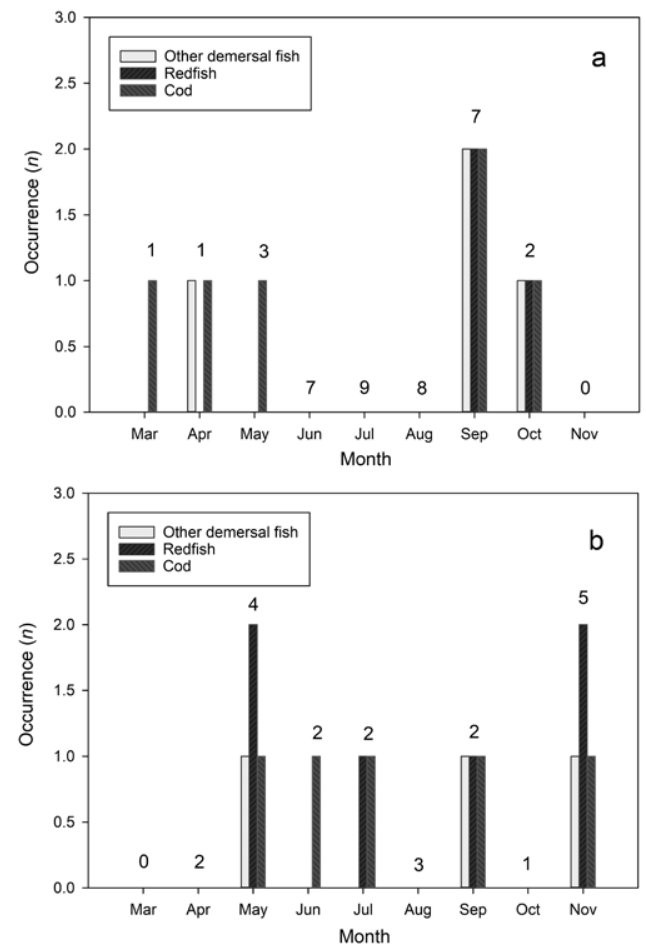

Figure 4. Seasonal occurrence of redfish (Sebastes spp.), cod species (either Gadus morhua or Gadus ogac), and other demersal fish species from the families Zoarcidae, Macrouridae, Liparidae, Cyplopteridae, and Cottidae in digestive tracts of a. female and b. male St. Lawrence Estuary Beluga (Delphinapterus leucas) collected between 1988 and 2019. Numbers of tracts with at least trace amounts of food are indicated above each set of bars.

were frequently ingested invertebrates in both studies. There was no obvious bias or difference in age- or sexclass sampling in Vladykov's nor our study; adults from both sexes were well represented in both studies, along with lower occurrences of calves and juveniles. However, sampling timing and location might explain some of the observed differences among studies; for instance, American Eel is more likely to be abundant in the fall in the SLE, particularly in the upper estuary (e.g., Vladykov 1946) or in the Saguenay River-times and places that were not sampled by Vladykov. Whether the absence of hake and redfish in Vladykov's study results from the strong sampling bias toward a sandy habitat no longer used by Beluga (the Manicouagan River mouth) or to a change in their availability over time is unknown. Temporal trend data for redfish are relatively recent; two summer studies from the 1930s and 1950s suggest that redfish were scarce in the SLE in the 1930s (Vladykov and Tremblay 1935 as cited in Steele 1957). 
TABLE 3. Average ( $\pm \mathrm{SE}$ ) fork length for Beluga (Delphinapterus leucas) prey, based on otolith length that were well preserved and moderately eroded (Class 1 and 2, respectively), and including eroded otoliths (all classes).

\begin{tabular}{|c|c|c|c|c|}
\hline \multirow{2}{*}{ Species } & \multicolumn{2}{|l|}{ Class 1 and 2} & \multicolumn{2}{|l|}{ All classes } \\
\hline & Mean length (cm) & $n$ & Mean length $(\mathrm{cm})$ & $n$ \\
\hline Sand lance (Ammodytes sp.) & 13.2 & 1 & $12.1(0.46)$ & 8 \\
\hline Atlantic Herring (Clupea harengus) & $28.5(0.85)$ & 10 & $23.6(1.64)$ & 20 \\
\hline Fourbeard Rockling (Enchelyopus cimbrius) & - & & $22.4(3.05)$ & 5 \\
\hline Atlantic Cod (Gadus morhua) & - & & $33.7(4.75)$ & 7 \\
\hline Atlantic Cod/Greenland Cod (Gadus morhua/Gadus ogac) & $40.8(0.91)$ & 10 & $30.0(0.71)$ & 137 \\
\hline Daubed Shanny (Leptoclinus maculatus) & - & & - & \\
\hline Lycodes (Lycodes sp.) & - & & $28.2(1.16)$ & 5 \\
\hline Capelin (Mallotus villosus) & $11.4(0.15)$ & 49 & $12.7(0.22)$ & 90 \\
\hline Silver Hake (Merluccius bilinearis) & - & & $29.6(0.57)$ & 26 \\
\hline Marlin-pike (Nezumia bairdii) & - & & $23.4(0.62)$ & 10 \\
\hline Rainbow Smelt (Osmerus mordax) & - & & $10.7(0.26)$ & 101 \\
\hline Redfish (Sebastes sp.) & - & & $20.2(0.40)$ & 92 \\
\hline Deepwater Redfish (Sebastes mentella) & $18.5(0.63)$ & 14 & - & \\
\hline White Hake (Urophycis tenuis) & - & & $45.9(2.97)$ & 4 \\
\hline
\end{tabular}

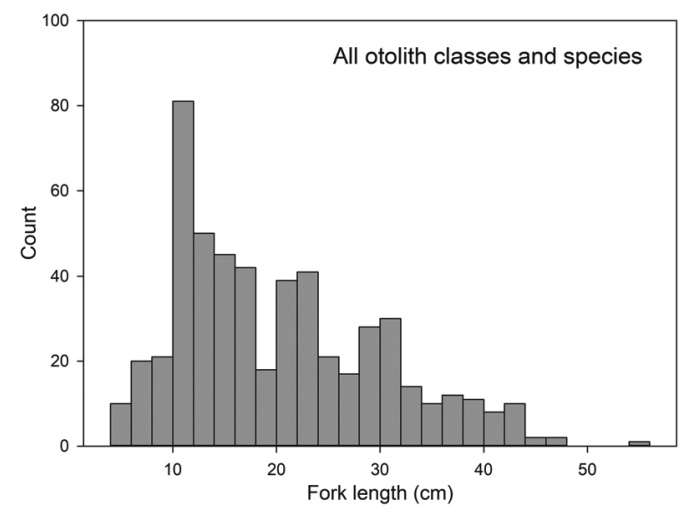

Figure 5. Frequency distribution of fish size estimated from the length of 533 otoliths recovered from digestive tracts of St. Lawrence Estuary Beluga (Delphinapterus leucas) that were found dead between 1988 and 2019. All otoliths that allowed identification of species (i.e., regardless of degree of degradation) were included in this analysis.

Otoliths are calcium carbonate structures that progressively deteriorate when exposed to gastric fluids, and at a different rate depending on size and robustness (Tollit et al. 1997). Our reliance on decomposing carcasses reduced the chances of detecting small otoliths that are typical of smaller species (e.g., sand lance and Capelin), possibly biasing prey relative occurrences. In contrast, cephalopod beaks and hard parts of polychaete worms can accumulate over a few meals, possibly overestimating their importance (Jobling and Breiby 1986; Tollit et al. 1997). While the presence of some benthic invertebrates in diges- tive tracts might have resulted from secondary ingestion or suction feeding on other prey, others such as Northern Atlantic Octopus, Northern Shortfin Squid, polychaete worms, and shrimp were in volumes compatible with direct ingestion (Vladykov 1946; Seaman et al. 1982; Lowry et al. 1985; Quakenbush et al. 2015).

Our study confirmed SLE Beluga past (Vladykov 1946) and present have a varied diet as they do elsewhere (Kleinenberg et al. 1964; Seaman et al. 1982; Heide-Jorgensen and Teilmann 1994; Hobbs et al. 2008; Quakenbush et al. 2015). Capelin was the most important prey for Beluga during early summer, with sand lance and demersal fish such as cod progressively replacing Capelin in late summer and early fall as water warmed, suggesting some seasonality in prey selection or availability (Vladykov 1946). There was no seasonal pattern detected in Capelin occurrence in our study. Spawning for Capelin begins around mid-April in the upper estuary and lasts until the end of June in the lower estuary (Jacquaz et al. 1977). The dominance of Capelin in our March and May samples supports their importance for Beluga at that period, but whether their ingestion is supplemented with other species at these times is unknown. There was evidence of seasonality for sand lance but also other species in our study. Sand lance along with American Eel, Rainbow Smelt, and Atlantic Herring were detected in Beluga diets exclusively in late summer and fall, whereas other species from the families Zoarcidae, Macrouridae, Liparidae, Cyplopteridae, and Cottidae were detected in spring and/or fall. The coincidence of SLE Beluga aggregation areas with 
sand lance habitat is also evidence for potential use of this species in recent years (Mosnier et al. 2016).

The St. Lawrence Estuary is a highly heterogeneous and dynamic environment, with expected effects on prey community structure and availability. The upper estuary is an area of shallow, warm water of relatively low salinity $(<26 \mathrm{ppm})$, whereas the lower estuary consists of the deep, cold, and saline water of the Laurentian Channel, and the shallower water of intermediate salinity and temperature of the south shore (El-Sabh et al. 1979; Figure 1). While some prey, such as Capelin, Atlantic Herring, and sand lance, are relatively abundant in both sectors, others are more abundant in, or are exclusive to, one or the other. This is the case for Atlantic Tomcod, American Eel, Smooth Flounder, American Shad (Alosa sapidissima), and Rainbow Smelt, that occur mainly, or are more abundant, in the upper estuary (Bourget 2011). Conversely, redfish, cod, hake, poachers, Greenland Halibut (Reinhardtius hippoglossoides), Northern Shortfin Squid, Sea Lamprey, lycodes, American Plaice (Hippoglossoides platessoides), and most skate species are more abundant or found exclusively in the lower estuary (Scallon-Chouinard et al. 2007).

The upper and lower estuary are used differentially by adult male and female Beluga during summer, consistent with the sex- and age-class spatial segregation documented for the species (Michaud 1993; Smith and Martin 1994; Smith et al. 1994; Richard et al. 1997; Heide-Jorgensen and Lockyer 2001; Loseto et al. 2006, 2008). In the SLE, adult females and juveniles use primarily the upper estuary and south shore of the lower estuary during summer, while large individuals (presumed to be adult males) concentrate mainly in the lower estuary (Michaud 1993; Figure 1). Adult males overlap with females and juveniles in the shallower waters of the lower estuary, and in the Saguenay River and river mouth. Our upper estuary sample was dominated by females ( $7 / 8$ carcasses) that had fed on a mix of small pelagic or bottom-dwelling fish and less on demersal fish. Our lower estuary sample was composed of individuals from both sexes, that had fed on multiple species of demersal fish. Isotopic mass balance models using a preliminary set of prey support the greater importance of demersal fish in the diet of males than females (Lesage 2014). These findings are also consistent with sex-specific isotopic and fatty acid signatures of SLE Beluga, and occupancy of higher trophic positions by males than females (Lesage et al. 2001; Nozères 2006; Lesage 2014).

Whether the spatial segregation among age and sex classes, with associated consequence on diet composition, extends in the spring and fall remains unclear. There is genetic evidence for a persistence of female-close kin, and male-male associations during the fall migration (Colbeck et al. 2013), although groups may share the same migration routes. In the SLE, support for a reduced spatial segregation outside summer comes from historical fall hunts of large adults (likely males) at Rivière-Ouelle in the upper estuary (Vladykov 1944), the spring report of a dead adult male full of Capelin in the same area (our study), and the concentration of most spring Beluga observations in the upper estuary (Michaud and Chadenet 1990). An overlap in distribution would make differential access to local prey communities less prominent outside summer, a prediction consistent with the lack of clear differences in diet composition between males and females in the spring and fall. The appearance of demersal fish in the female diet in spring or fall (while males consumed these species in all seasons) might reflect their greater use of the lower estuary outside of summer.

Beluga are size dimorphic, with males being larger than females (Lesage et al. 2014). Allometric relationships predict that males would be able to ingest larger prey items and a wider range of species (Wilson 1975), and reach deeper depths than females (Schreer and Kovacs 1997), predictions that were verified in other Beluga populations (Seaman et al. 1982; Lowry et al. 1985; Szpak et al. 2019). In the SLE, differential prey access by sexes due to diving capacity is unlikely given that maximum bottom depth $(350 \mathrm{~m})$ is shallower than the species diving capacity (in excess of $1100 \mathrm{~m}$; Richard et al. 1997). While our sample was too small to document sex differences in ingested prey size, Vladykov (1946) reported adult males ingested larger fish such as cod and sculpins, and females ate smaller prey such as squid, polychaete worms, and sand lance more frequently. Beluga swallow prey whole (Quakenbush et al. 2015), and feed using suction (Brodie 1969), a strategy particularly efficient for capturing squid or capelin (Werth 2000) or when feeding on benthic or concealed prey such as sand lance and polychaete worms (Kane and Marshall 2009), where substrate enhances effective suction distances (Nauwelaerts et al. 2008). While suction feeding may theoretically limit prey size, as suggested by Vladykov (1946), reports of Alaskan Beluga ingesting whole Coho (Oncorhynchus kisutch) or Chum Salmon (Oncorhynchus keta) $60 \mathrm{~cm}$ or more in size (Quakenbush et al. 2015), suggest that SLE Beluga preference for prey $<30 \mathrm{~cm}$ and on average $20 \mathrm{~cm}$ in length is unrelated to anatomical or feeding mode limitations.

Local prey availability likely explained the fall ingestion of American Eel, Rainbow Smelt, and Atlantic Tomcod as these catadromous or anadromous species are present or particularly abundant in the SLE at that time of year, especially in the upper 
estuary (Casgrain 1873; Vladykov 1946; Bourget 2011). Atlantic Herring spawns in multiple localities in the SLE in both spring and fall (Munro et al. 1998) and are particularly lipid-rich just before spawning. The scarcity of Atlantic Herring in SLE Beluga diet in this study and that of Vladykov (1946) may reflect our inability to capture this short event in our sample, the mismatch between Vladykov sampling sites and Atlantic Herring spawning sites, or the preference of Beluga for laid eggs instead of Atlantic Herring themselves (i.e., absence of hard parts; Vladykov 1946). Observations of persistently large numbers of SLE Beluga (hourly average of 70 to 80 Beluga) in a known Atlantic Herring spawning area during spring spawning (late May; Lesage and Kingsley 1995), and hunter reports of Beluga eating substantial amounts of Atlantic Herring in the spring at Rivière-Ouelle and near Ile Verte (north of Rivière-du-Loup, Quebec, Canada; Vladykov 1946) highlight their likely importance for SLE Beluga at least at that time of year.

Beluga are considered opportunistic feeders, but there might be prey or feeding times that are key to their fitness and survival, even though there was no evidence of a cycle of fast and feast in either Vladykov's (1946) or our study (Figure 2). Peak calving is in July for SLE Beluga (Sergeant 1986), and captivity studies indicate that energy intake increases 1.5- to 2-fold during the last two months of pregnancy. It peaks at four times normal during the first month after birth and remains at 1.5 to 2 times normal for the following three months of lactation (Kastelein et al. 1994). Accordingly, energy demands on pregnant SLE Beluga females start rising in May and remain high through at least early fall. Casgrain (1873) reported that SLE Beluga at Rivière-Ouelle in the spring are thin and voracious, feeding on Capelin and Rainbow Smelt in such a way that they put on 13 to 15 $\mathrm{cm}$, sometimes $20 \mathrm{~cm}$ of fat in 8-10 days. Although the reported gain in blubber thickness appears extreme, these observations suggest that spring feeding might be critical in SLE Beluga for replenishing fat stores just before entering the last months of the gestation and calving period. Vladykov (1946), based on condition and stomach fullness indices, suggest that Beluga are fat in June, less in July and August, and fatter again in September. If this is the case, then spring and fall spawning species such as Capelin and Atlantic Herring, and catadromous or diadromous prey such as Rainbow Smelt, and possibly the large demersal fish that gain in importance in female diet in the fall, might be important for Beluga. Capelin and sand lance are still present in the SLE (e.g., Dutil et al. 2009), but their abundance is unknown. In Newfoundland, Capelin stocks have collapsed in recent decades (Buren et al. 2019); whether similar patterns prevail in the SLE and Gulf of St. Lawrence is unknown (DFO 2015). Stock abundance of other species such as spring Atlantic Herring, Rainbow Smelt, American Eel, and Atlantic Cod, are known to be considerably reduced compared to historical levels (Mingelbier et al. 2001; DFO 2010, 2019; Swain 2016; Équipe de Rétablissement de l'Éperlan arc-enciel, population du sud de l'estuaire du Saint-Laurent 2019). Whether the SLE Beluga recent high female and calf mortality rates (Lair et al. 2016; Gosselin et al. 2017) and failure to recover since the 1980s might at least be partially related to inadequate access to lipid-rich food at crucial times cannot be dismissed, and warrants further investigation. In eastern Beaufort Sea Beluga, there are concerns that the low body condition index (based on blubber thickness) reported in recent years might be caused by a lower availability of Arctic Cod (Boreogadus saida; Choy et al. 2017), and ingestion of prey of a lower lipid quality requiring higher energy output for their capture (Loseto et al. 2018).

At a time when several Beluga populations worldwide are threatened by previous overhunting and habitat degradation (i.e., COSEWIC 2004; National Marine Fisheries Service 2016), access to information on current and past diet and seasonal feeding cycles is critical for predicting and mitigating potential impacts of anthropogenic activity and climate at times and places where they matter the most. While our sample size was too small to quantitatively evaluate the contemporary diet of SLE Beluga, our results indicate that fish from stocks believed to be depleted (Atlantic Cod, American Eel) or that are now recovering (Striped Bass, redfish) should be considered as possible prey and not dismissed from diet estimations using quantitative models based on molecular tracers, or when trying to understand current contamination sources affecting this population. Approaches for investigating diet should also consider seasonality in prey availability and quality, and inter-individual diet variability as mechanisms for reducing potential competition (Tinker et al. 2008).

\section{Author Contributions}

Writing - Original Draft: V.L.; Writing - Review \& Editing: S.L., S.T., and P.B.; Conceptualization: V.L.; Investigation: V.L., S.L., S.T., and P.B.; Methodology: V.L. and S.T.; Formal Analysis: V.L. and S.T.; Funding Acquisition: V.L.

\section{Acknowledgements}

We thank Carl Guimont and Richard Plante from FILMAR Industries, and the many people who helped with collection of carcasses over the study period. We thank also Drs. Daniel Martineau, Christiane Girard, André Dallaire, Igor Mikaelian, Sylvain De 
Guise, and the many students and technical staff from the University de Montréal Veterinary College who helped with Beluga necropsies over the years, as well as Dr. Lena Measures and the Réseau Québecois d'Urgence pour les Mammifères Marins for coordinating the carcass recovery network. Pierre Carter, Johanne Guérin, Pierre Rivard, Susan Crockford, and Roberta Miller assisted with the identification of prey remains, and J.-F. Ouellet produced the map. We thank Jory Cabrol and two anonymous reviewers for their help improving the manuscript. This study was supported by Fisheries and Oceans Canada and Parks Canada.

\section{Literature Cited}

Bourget, G. 2011. Réseau d'inventaire des poissons de l'estuaire (RIPE) - Bilan de l'année 2009. Ministère des Ressources naturelles et de la Faune, Direction de l'expertise Faune-Forets-Territoire, Direction générale du Bas-Saint-Laurent. Accessed 28 February 2020. http:// collections.banq.qc.ca/ark:/52327/bs2433594.

Bowen, W.D. 1997. Role of marine mammals in aquatic ecosystems. Marine Ecology Progress Series 158: 267274. https://doi.org/10.3354/meps158267

Bowen, W.D., and G.D. Harrison. 1996. Comparison of harbour seal diets in two inshore habitats of Atlantic Canada. Canadian Journal of Zoology 74: 125-135. https://doi.org/10/1139/z96-017

Brassard, C., H. Bourdages, D. Duplisia, J. Gauthier, and A. Valentin. 2017. The status of the redfish stocks (Sebastes fasciatus and S. mentella) in Unit 1 (Gulf of St. Lawrence) in 2015. DFO Canadian Science Advisory Secretariat, Research Document 2017/023. Accessed 28 February 2020. https://waves-vagues.dfo-mpo.gc.ca/ Library/40605243.pdf.

Brodie, P.F. 1969. Mandibular layering in Delphinapterus leucas and age determination. Nature 221: 956-958. https://doi.org/10.1038/221956a0

Brodie, P.F. 1971. A reconsideration of aspects of growth, reproduction, and behavior of the white whale (Delphinapterus leucas), with reference to the Cumberland Sound, Baffin Island, population. Journal of the Fisheries Research Board of Canada 28: 1309-1318. https:// doi.org/10.1139/f71-198

Buren, A.J., H.M. Murphy, A.T. Adamack, G.K. Davoren, M. Koen-Alonso, W.A. Montevecchi, F.K. Mowbray, P. Pepin, P.M. Regular, D. Robert, G.A. Rose, G.B. Stenson, and D. Varkey. 2019. The collapse and continued low productivity of a keystone forage fish species. Marine Ecology Progress Series 616: 155-170. https://doi.org/10.3354/meps12924

Cairns, D.K., G. Chaput, L.A. Poirier, T.S. Avery, M. Castonguay, A. Mathers, J.M. Casselman, R.G. Bradford, T. Pratt, G. Verreault, K. Clarke, G. Veinott, and L. Bernatchez. 2014. Recovery potential assessment for the American eel (Anguilla rostrata) for eastern Canada: life history, distribution, reported landings, status indicators, and demographic parameters. DFO Canadian Science Advisory Secretariat, Research
Document 2013/134. Accessed 6 April 2020. https:// waves-vagues.dfo-mpo.gc.ca/Library/360883.pdf.

Canada Gazette. 2016. Order amending Schedule 1 to the Species at Risk Act. Accessed 28 February 2020. http:// canadagazette.gc.ca/rp-pr/p1/2016/2016-08-27/html/ reg1-eng.html.

Casgrain, Abbé. 1873. La pêche aux marsouins dans le fleuve Saint-Laurent. Montréal. Published without author name. Accessed 28 February 2020. https://ia802906. us.archive.org/12/items/cihm_00526/cihm_00526.pdf.

Choy, E.S., B. Rosenberg, J.D. Roth, and L.L. Loseto. 2017. Inter-annual variation in environmental factors affect the prey and body condition of beluga whales in the eastern Beaufort Sea. Marine Ecology Progress Series 579: 213-225. https://doi.org/10.3354/meps12256

Clarke, M.R. 1986. A Handbook for the Identification of Cephalopod Beaks. Clarendon Press, Oxford, United Kingdom.

Colbeck, G.J., P. Duchesne, L.D. Postma, V. Lesage, M.O. Hammill, and J. Turgeon. 2013. Groups of related belugas (Delphinapterus leucas) travel together during their seasonal migrations in and around Hudson Bay. Proceedings of the Royal Society B: Biological Sciences 280: 20122552. https://doi.org/10.1098/rspb. 2012.2552

COSEWIC (Committee on the Status of Endangered Wildlife in Canada). 2004. COSEWIC assessment and update status report on the Beluga Delphinapterus leucas in Canada. COSEWIC, Ottawa, Ontario, Canada.

COSEWIC (Committee on the Status of Endangered Wildlife in Canada). 2012. COSEWIC assessment and status report on the Striped Bass Morone saxatilis in Canada. COSEWIC, Ottawa, Ontario, Canada.

COSEWIC (Committee on the Status of Endangered Wildlife in Canada). 2014. COSEWIC assessment and status report on the Beluga Whale Delphinapterus leucas, St. Lawrence Estuary population, in Canada. COSEWIC, Ottawa, Ontario, Canada.

DFO (Fisheries and Oceans Canada). 2010. Status of American Eel and progress on achieving management goals. DFO Canadian Science Advisory Secretariat, Science Advisory Report 2010/062. Accessed 6 April 2020. https://waves-vagues.dfo-mpo.gc.ca/Library/342 640.pdf.

DFO (Fisheries and Oceans Canada). 2014. Status of Beluga(Delphinapterus leucas) in the St. Lawrence River estuary. DFO Canadian Science Advisory Secretariat, Science Advisory Report 2013/076. Accessed 6 April 2020. https://waves-vagues.dfo-mpo.gc.ca/Library/3610 43.pdf.

DFO (Fisheries and Oceans Canada). 2015. Update of indicators of the status of the Estuary and Gulf of St. Lawrence (Divisions 4RST) Capelin stock in 2014. DFO Canadian Science Advisory Secretariat, Science Response 2015/032. Accessed 6 April 2020. https:// waves-vagues.dfo-mpo.gc.ca/Library/363796.pdf.

DFO (Fisheries and Oceans Canada). 2017. Information in support of Critical Habitat identification for Striped Bass (Morone saxatilis) of the St. Lawrence River. DFO Canadian Science Advisory Secretariat, Science Advisory Report 2017/001. Accessed 6 April 2020. 
https://waves-vagues.dfo-mpo.gc.ca/Library/40597234. pdf.

DFO (Fisheries and Oceans Canada). 2019. Assessment of Atlantic Cod (Gadus morhua) in the southern Gulf of St. Lawrence (NAFO Div. 4T-4Vn (Nov.-April)) to 2018. DFO Canadian Science Advisory Secretariat, Science Advisory Report 2019/021. Accessed 6 April 2020. http:// www.dfo-mpo.gc.ca/csas-sccs/Publications/SAR-AS/ 2019/2019_021-eng.pdf.

Dutil, J.-D., C. Nozères, P.-M. Scallon-Chouinard, L. Van Guelpen, D. Bernier, S. Proulx, R. Miller, et C. Savenkoff. 2009. Poissons connus et méconnus des fonds marins du Saint-Laurent. Naturaliste canadien 133: 70-82.

EI-Sabh, M.I., E. Bourget, M.J. Bewers, et J.-C. Dionne. 1979. L'océanographie de l'estuaire du Saint-Laurent. Naturaliste canadien 106: 1-276.

Équipe de Rétablissement de l'éperlan arc-en-ciel, population du sud de l'estuaire du Saint-Laurent. 2019. Bilan du rétablissement de l'éperlan arc-enciel (Osmerus mordax) au Québec, population du sud de l'estuaire du Saint-Laurent pour la période 20082016. Le ministère des Forêts, de la Faune et des Parcs, Direction générale de la gestion de la faune et des habitats. Quebec, Canada. Accessed 16 December 2019. https://mffp.gouv.qc.ca/documents/faune/bilan retablissement_eperlan_arc-en-ciel_2008-2016.pdf.

Gavrilchuk, K., V. Lesage, C. Ramp, R. Sears, M. Bérubé, S. Bearhop, and G. Beauplet. 2014. Trophic niche partitioning among sympatric baleen whale species following the collapse of groundfish stocks in the Northwest Atlantic. Marine Ecology Progress Series 497: 285-301. https://doi.org/10.3354/meps10578

Geracy, J.R., and V.J. Lounsbury. 1993. Marine Mammals Ashore: a Field Guide for Strandings. Texas A\&M Sea Grant College Program, Galveston, Texas, USA.

Gosselin, J.-F., M.O. Hammill, A. Mosnier, and V. Lesage. 2017. Abundance index of St. Lawrence Estuary beluga, Delphinapterus leucas, from aerial visual surveys flown in August 2014 and an update on reported deaths. DFO Canadian Science Advisory Secretariat, Research Document 2017/019. Accessed 6 April 2020. https://waves-vagues.dfo-mpo.gc.ca/Library/40603854. pdf.

Hammill, M.O., W.D. Bowen, and B. Sjare. 2010. Status of Harbour Seals (Phoca vitulina) in Atlantic Canada. NAMMCO Scientific Publications 8: 175-190. https:// doi.org/10.7557/3.2684

Hammill, M.O., C.E. den Heyer, W.D. Bowen, and S.L.C. Lang. 2017. Grey Seal population trends in Canadian waters, 1960-2016 and harvest advice. DFO Canadian Science Advisory Secretariat, Research Document 2017/ 052. Accessed 6 April 2020. https://waves-vagues.dfompo.gc.ca/Library/40643542.pdf.

Hammill, M.O., V. Lesage, and P. Carter. 2005. What do harp seals eat? Comparing diet composition from different compartments of the digestive tract with diets estimated from stable isotope ratios. Canadian Journal of Zoology 83: 1365-1372. https://doi.org/10.1139/Z05-123

Hammill, M.O., and G.B. Stenson. 2006. Abundance of Northwest Atlantic hooded seals (1960-2005). DFO
Canadian Science Advisory Secretariat, Research Document 2006/068. Accessed 6 April 2020. https:// waves-vagues.dfo-mpo.gc.ca/Library/329037.pdf.

Hammill, M.O., G.B. Stenson, T. Doniol-Valcroze, and A. Mosnier. 2015. Conservation of Northwest Atlantic harp seals: past success, future uncertainty? Biological Conservation 192: 181-191. https://doi.org/10.1016/j.bio con.2015.09.016

Hammill, M.O., G.B. Stenson, F. Proust, P. Carter, and D. McKinnon. 2007. Feeding by grey seals in the Gulf of St. Lawrence and around Newfoundland. NAMMCO Scientific Publications 6: 135-152. https:// doi.org/10.7557/3.2729

Harington, C.R. 1977. Marine mammals in the Champlain Sea and the Great Lakes. Annals of the New York Academy of Science 288: 508-537. https://doi.org/10.1111/j. 1749-6632.1977.tb33640.x

Heide-Jørgensen, M.-P., and C. Lockyer. 2001. Age and sex distributions in the catches of Belugas, Delphinapterus leucas, in West Greenland and in western Russia. Mammalian Biology 66: 215-227.

Heide-Jørgensen, M.P., and J. Teilmann. 1994. Growth, reproduction, age structure and feeding habits of white whales (Delphinapterus leucas) in West Greenland waters. Meddelelser om Grøenland Bioscience 39: 195-212.

Hickie, B.E., M.C.S. Kingsley, P.V. Hodson, D.C.G. Muir, P. Béland, and D. Mackay. 2000. A modelling-based perspective on the past, present, and future polychlorinated biphenyl contamination of the St. Lawrence beluga whale (Delphinapterus leucas) population. Journal of Fisheries and Aquatic Sciences 57(Supplement 1): 101112. https://doi.org/10.1139/f99-242

Hobbs, R.C., K.E.W. Shelden, D.J. Rugh, and S.A. Norman. 2008. Status review and extinction risk assessment of Cook Inlet belugas (Delphinapterus leucas). Alaska Fisheries Science Center, NOAA, National Marine Fisheries Service, 7600 Sand Point. Accessed 28 February 2020. https://www.afsc.noaa.gov/Publications/ ProcRpt/PR\%202006-16.pdf.

Hohn, A.A., C. Lockyer, and M. Acquarone. 2016. Report of the workshop on age estimation in monodontids. Tampa, FL, USA. 26-27 November 2011. https://doi.org/ $10.7557 / 3.3743$

Iverson, S.J., C. Field, W.D. Bowen, and W. Blanchard. 2004. Quantitative fatty acid signature analysis: a new method of estimating predator diets. Ecological Monographs 74: 211-235. https://doi.org/10.1890/02-4105

Jacquaz, B., K.W. Able, and W.C. Leggett. 1977. Seasonal distribution, abundance, and growth of larval capelin (Mallotus villosus) in the St. Lawrence Estuary and northwestern Gulf of St. Lawrence. Journal of the Fisheries Research Board of Canada 34: 2008-2014. https://doi.org/10.1139/cjfas-2013-0227

Jobling, M., and A. Breiby. 1986. The use and abuse of fish otoliths in studies of feeding habits of marine piscivores. Sarsia 71: 265-274. https://doi.org/10.1080/00364 827.1986 .10419696

Kane, E.A., and C.D. Marshall. 2009. Comparative feeding kinematics and performance of odontocetes Belugas, Pacific white-sided dolphins and long-finned pilot whales. Journal of Experimental Biology 212: 
3939-3950. https://doi.org/10.1242/jeb.034686

Kastelein, R.A., J. Ford, E. Berghout, P.R. Wiepkema, and M. van Boxsel. 1994. Food consumption, growth and reproduction of belugas (Delphinapterus leucas) in human care. Aquatic Mammals 20: 81-97.

Kleinenberg, S.E., A. Yablokov, B.M. Belkovich, and M.N. Tarasevich. 1964. Beluga (Delphinapterus leucas): investigation of the species. Israel Program for Scientific Translations, Jerusalem, No. TT-67-51345 (original publication in Russian).

Lair, S., L.N. Measures, and D. Martineau. 2016. Pathological findings and trends in mortality in the beluga (Dephinapterus leucas) population of the St. Lawrence Estuary, Québec, Canada, from 1983 to 2012. Veterinary Pathology 53: 22-36. https://doi.org/10.1177/ 0300985815604726

Lesage, V. 2014. Trends in the trophic ecology of St. Lawrence beluga (Delphinapterus leucas) over the period 1988-2012, based on stable isotope analysis. DFO Canadian Science Advisory Secretariat, Research Document 2013/126. Accessed 6 April 2020. https:// waves-vagues.dfo-mpo.gc.ca/Library/361182.pdf.

Lesage, V., M.O. Hammill, and K.M. Kovacs. 2001. Marine mammals and the community structure of the Estuary and Gulf of St. Lawrence, Canada: evidence from stable isotope analysis. Marine Ecology Progress Series 210: 203-221.

Lesage, V., et M.C.S. Kingsley. 1995. Bilan des connaissances de la population de bélugas (Delphinapterus leucas) du Saint-Laurent. Rapport technique canadien des sciences halieutiques et aquatiques 2041. Accessed 5 March 2020. https://waves-vagues.dfo-mpo.gc.ca/ Library/184023.pdf.

Lesage, V., L. Measures, A. Mosnier, S. Lair, and P. Béland. 2014. Mortality patterns in St. Lawrence Estuary beluga (Delphinapterus leucas), inferred from the carcass recovery data, 1983-2012. DFO Canadian Science Advisory Secretariat, Research Document 2013/ 118. Accessed 6 April 2020. https://waves-vagues.dfompo.gc.ca/Library/361254.pdf.

Loseto, L.L., J.D. Brewster, S.K. Ostertag, K. Snow, S.A. MacPhee, D.G. McNicholl, E.S. Cho, C. Giraldo, and C.A. Hornby. 2018. Diet and feeding observations from an unusual beluga harvest in 2014 near Ulukhaktok, Northwest Territories, Canada. Arctic Science 4: 421431. https://doi.org/10.1139/as-2017-0046

Loseto, L.L., P. Richard, G.A. Stern, J. Orr, and S.H. Ferguson. 2006. Segregation of Beaufort Sea beluga whales during the open-water season. Canadian Journal of Zoology 84: 1743-1751. https://doi.org/10.1139/z06160

Loseto, L.L., G.A. Stern, and S.H. Ferguson. 2008. Size and biomagnification: how habitat selection explains beluga mercury levels. Environmental Science and Technology 42: 3982-3988. https://doi.org/10.1021/ es7024388

Lowry, L.F., K.J. Frost, and G.A. Seaman. 1985. Investigations of belukha whales in coastal waters of western and northern Alaska. III. Food habits. Alaska Department of Fish and Game, Fairbanks, Alaska. Accessed 28 February 2020. http://www.adfg.alaska. gov/static/home/library/pdfs/wildlife/federal_aid/85 lowry_etal_belukha_western_northern_ak_phase_i. pdf.

Matthews, C.J.D., and S.H. Ferguson. 2015. Weaning age variation in beluga whales (Delphinapterus leucas). Journal of Mammalogy 96: 425-437. https://oi.org/ 10.1093/jmammal/gyv046

Michaud, R. 1993. Distribution estivale du béluga du SaintLaurent; synthèse 1986 à 1992. Rapport technique canadien des sciences halieutiques et aquatiques 1906 . Accessed 28 February 2020. https://waves-vagues.dfompo.gc.ca/Library/145880.pdf.

Michaud, R., et V. Chadenet. 1990. Survols aériens pour l'estimation de la distribution printanière des bélugas du Saint-Laurent. INESL, Rimouski (QC). GREMM, Tadoussac, Quebec, Canada.

Mingelbier, M., F. Lecomte, and J.J. Dodson. 2001. Climate change and abundance cycles of two sympatric populations of smelt (Osmerus mordax) in the middle estuary of the St. Lawrence river, Canada. Canadian Journal of Fisheries and Aquatic Sciences 58: 20482058. https://doi.org/10.1139/cjfas-58-10-2048

Moore, J.W., and B.X. Semmens. 2008. Incorporating uncertainty and prior information into stable isotope mixing models. Ecology Letters 11: 470-480. https://doi. org/10.1111/j.1461-0248.2008.01163.x

Mosnier, A., T. Doniol-Valcroze, J.-F. Gosselin, V. Lesage, L.M. Measures, and M.O. Hammill. 2015. Insights into processes of population decline using an integrated population model: the case of the St. Lawrence beluga (Delphinapterus leucas). Ecological Modelling 314: 15-31. https://doi.org/10.1016/j.ecolmodel.2015.07. 006

Mosnier, A., R. Larocque, M. Lebeuf, J.-F. Gosselin, S. Dubé, V. Lapointe, V. Lesage, D. Lefaivre, S. Senneville, et C. Chion. 2016. Définition et caractérisation de l'habitat du béluga (Delphinapterus leucas) de l'estuaire du Saint-Laurent selon une approche écosystémique. Secrétariat canadien de consultation scientifique du MPO, Document de recherche 2016/052. Accessed 6 April 2020. https://waves-vagues.dfo-mpo. gc.ca/Library/365829.pdf.

Munro, J., D. Gauthier, et J.A. Gagné. 1998. Description d'une frayère de hareng (Clupea harengus L.) à l'îleaux-Lièvres dans l'estuaire moyen du Saint-Laurent. Rapport technique canadien des sciences halieutiques et aquatiques 2239. Accessed 28 February 2020. https:// waves-vagues.dfo-mpo.gc.ca/Library/229992.pdf.

Murie, D.J., and D.M. Lavigne. 1986. Interpretation of otoliths in stomach content analyses of phocid seals: quantifying fish consumption. Canadian Journal of Zoology 64: 1152-1157. https://doi.org/10.1139/z86-174

National Marine Fisheries Service. 2016. Recovery plan for the Cook Inlet Beluga Whale (Delphinapterus leucas). National Marine Fisheries Service, Alaska Region, Protected Resources Division, Juneau, Alaska. Accessed 6 April 2020. https://repository.library.noaa. gov/view/noaa/15979.

Nauwelaerts, S., C.D. Wilga, G.V. Lauder, and C.P. Sanford. 2008. Fluid dynamics of feeding behaviour in white-spotted bamboo sharks. Journal of Experimental 
Biology 211: 3095-3102. https://doi.org/10.1242/jeb.01 9059

Nozères, C.A. 2006. Régime alimentaire du béluga de l'estuaire du St Laurent, Canada, tel que révélé par l'analyse des acides gras du lard. M.Sc. thesis, Laval University, Québec City, Quebec, Canada.

Parnell, A.C., R. Inger, S. Bearhop, and A.L. Jackson. 2010. Source partitioning using stable isotopes: coping with too much variation. PLoS ONE 5: e9672. https:// doi.org/10.1371/journal.pone.0009672

Pierce, G.J., and P.R. Boyle. 1991. A review of methods for diet analysis in piscivorous marine mammals. Oceanography and Marine Biology 29: 409-486.

Plourde, S., P. Galbraith, V. Lesage, F. Grégoire, H. Bourdgages, J.-F. Gosselin, I. McQuinn, and M. Scarratt. 2014. Ecosystem perspective on changes and anomalies in the Gulf of St. Lawrence: a context in support of the management of the St. Lawrence beluga whale population.DFOCanadian Science Advisory Secretariat, Research Document 2013/129. Accessed 6 April 2020. https://waves-vagues.dfo-mpo.gc.ca/Library/3609 87.pdf.

Proust, F. 1996. Composition du régime alimentaire du phoque gris (Halichoerus grypus) dans le Golfe du Saint-Laurent, Québec, Canada. M.Sc. thesis, Université du Québec à Rimouski, Rimouski, Quebec, Canada.

Quakenbush, L.T., R.S. Suydam, A.L. Bryan, L.F. Lowry, K.J. Frost, and B.A. Mahoney. 2015. Diet of Beluga Whales, Delphinapterus leucas, in Alaska from stomach contents, March-November. Marine Fisheries Review 77: 70-84. https://doi.org/10.7755/mfr.77.1.7

Richard, P.R., A.R. Martin, and J.R. Orr. 1997. Study of summer and fall movements and dive behaviour of Beaufort Sea belugas, using satellite telemetry: 19921995. Environmental Studies Research Fund Reports 134. Calgary, Alberta, Canada.

Salton, M., R. Kirkwood, D. Slip, and R. Harcourt. 2019. Mechanisms for sex-based segregation in foraging behaviour by a polygenous marine carnivore. Marine Ecology Progress Series 624: 213-226. https://doi. org/10.3354/meps13036

Savenkoff, C., M. Castonguay, D. Chabot, M.O. Hammill, H. Bourdages, and L. Morissette. 2007. Changes in the northern Gulf of St. Lawrence ecosystem estimated by inverse modelling: evidence of a fishery-induced regime shift? Estuarine, Coastal and Shelf Science 73: 711-724. https://doi.org/10.1016/j.ecss.2007.03.011

Scallon-Chouinard, P.-M., J.-D. Dutil, et S. Hurtubise. 2007. Liste des espèces de poissons inventoriées dans l'estuaire maritime du Saint-Laurent entre 1930 et 2005. Rapport technique canadien des sciences halieutiques et aquatiques 2719. Accessed 28 February 2020. https:// waves-vagues.dfo-mpo.gc.ca/Library/328614.pdf.

Schreer, J.F., and K.M. Kovacs. 1997. Allometry of diving capacity in air-breathing vertebrates. Canadian Journal of Zoology 75: 339-358. https://doi.org/10.1139/z97-044

Seaman, G.A., L.F. Lowry, and K.J. Frost. 1982. Foods of belukha whales (Delphinapterus leucas) in western Alaska. Cetology 44: 1-19.

Sergeant, D.E. 1986. Present status of white whales
Delphinapterus leucas in the St. Lawrence Estuary. Naturaliste canadien 113: 61-81.

Smith, T.G., M.O. Hammill, and A.R. Martin. 1994. Herd composition and behaviour of Belugas, Delphinapterus leucas, in two Canadian Arctic estuaries. Meddelelser om Grøenland Bioscience 39: 175-184.

Smith, T.G., and A.R. Martin. 1994. Distribution and movements of Belugas, Delphinapterus leucas, in the Canadian High Arctic. Canadian Journal of Fisheries and Aquatic Sciences 51: 1653-1663. https://doi.org/10. 1139/f94-166

Steele, D.H. 1957. The Redfish (Sebastes marinus L.) in the western Gulf of St. Lawrence. Journal of the Fisheries Research Board of Canada 14: 899-924. https://doi.org/ 10.1139/f57-038

Stenseth, N.C., G. Ottersen, J.W. Hurrell, and A. Belgrano. 2004. Marine Ecosystems and Climate Variation. Oxford University Press, Oxford, United Kingdom.

Stephens, D.W., and J.R. Krebs. 1986. Foraging Theory. Princeton University Press, Princeton, New Jersey, USA.

Stevick, P.T., J. Allen, P.J. Clapham, N. Friday, S.K. Katona, F. Larsen, J. Lien, D.K. Mattila, P.J. Palsbøll, J. Sigurjónsson, T.D. Smith, N. Øien, and P.S. Hammond. 2003. North Atlantic humpback whale abundance and rate of increase four decades after protection from whaling. Marine Ecology Progress Series 258: 263-273. https://doi.org/10.3354/meps258263

Stewart, R.E.A., S.E. Campana, C.M. Jones, and B.E. Stewart. 2006. Bomb radiocarbon dating calibrates beluga (Delphinapterus leucas) age estimates. Canadian Journal of Zoology 84: 1840-1852. https://doi.org/10. 1111/mms. 12655

Swain, D.P. 2016. Population modelling results for the assessment of Atlantic herring (Clupea harengus) stocks in the southern Gulf of St. Lawrence (NAFO Division 4T) to 2015. DFO Canadian Science Advisory Secretariat, Research Document 2016/061. Accessed 6 April 2020. https://waves-vagues.dfo-mpo.gc.ca/Library/365970.pdf.

Szpak, P., M.-H. Julien, T.C.A. Royle, J.M. Savelle, D.Y. Yang, and M.P. Richards. 2019. Sexual differences in the foraging ecology of 19th century beluga whales (Delphinapterus leucas) from the Canadian High Arctic. Marine Mammal Science 2019: 1-21. https://doi.org/ 10.1111/mms.12655

Tinker, M.T., G. Bentall, and J.A. Estes. 2008. Food limitation leads to behavioral diversification and dietary specialization in sea otters. Proceedings of the National Academy of Science 105: 560-565. https://doi. org/10.1073/pnas.0709263105

Tollit, D.J., M.J. Stewart, P.M. Thompson, G.J. Pierce, M.B. Santos, and S. Hugues. 1997. Species and size differences in the digestion of otoliths and beaks: implications for estimates of pinniped diet composition. Canadian Journal of Fisheries and Aquatic Sciences 54: 105-119. https://doi.org/10.1139/f96-264

Vanalderweireldt, L. 2019. Le retour du bar rayé dans l'estuaire du Saint-Laurent: écoogie des jeunes stades de vie et caractérisation des habitats essentiels. Ph.D. thesis, Université du Québec à Montréal, Quebec, Canada. Vladykov, V.D. 1944. Études sur les mammifères aqua- 
tiques. III. Chasse, biologie et valeur économique du marsouin blanc ou béluga (Delphinapterus leucas) du fleuve et du golfe du Saint-Laurent. Département des Pêcheries, Québec City, Quebec, Canada.

Vladykov, V.D. 1946. Etudes sur les mammifères aquatiques. IV. Nourriture du marsouin blanc ou béluga (Delphinapterus leucas) du fleuve Saint-Laurent. Département des Pêcheries, Québec City, Quebec, Canada.

Waugh, D.A., R.S. Suydam, J.D. Ortiz, and J.G.M. Thewissen. 2018. Validation of Growth Layer Group (GLG) depositional rate using daily incremental growth lines in the dentin of beluga (Delphinapterus leucas (Pallas, 1776)) teeth. PLoS ONE 13: e0190498. https:// doi.org/10.1371/journal.pone.0190498
Werth, A.J. 2000. Feeding in marine mammals. Pages 487-526 in Feeding: Form, Function and Evolution in Tetrapod Vertebrates. Edited by K. Schwenk. Academic Press, San Diego, California, USA.

Wilson, D.S. 1975. The adequacy of body size as a niche difference. American Naturalist: 109: 769-784. https:// doi.org/10.1086/283042

Worm, B., and R.A. Myers. 2003. Meta-analysis of codshrimp interactions reveals top-down control in oceanic food webs. Ecology 84: 162-173. https://doi.org/10. 1890/0012-9658(2003)084[0162:maocsi]2.0.co;2

Received 18 December 2019

Accepted 4 March 2020

\section{SuPPlementary Material:}

TABLE S1. Numerical abundance of fish and invertebrate species in the digestive tracts of Beluga (Delphinapterus leucas) collected in various regions of the St. Lawrence Estuary through Beluga carcass recovery, 1989-2019. 